\title{
Bee nutrition and floral resource restoration
}

Anthony D. Vaudo (adv124@psu.edu)*, John F. Tooker (tooker@psu.edu), Christina M. Grozinger (cmgrozinger@psu.edu), Harland M. Patch (hmpatch@psu.edu)

Department of Entomology, Center for Pollinator Research, The Pennsylvania State University, 501 ASI Building, University Park, PA 16802, USA

* Corresponding Author:

Anthony D. Vaudo

101 Merkle Building

The Pennsylvania State University

University Park, PA 16802

(407) 463-0861

adv124@psu.edu

\section{Abstract}

Bee-population declines are linked to nutritional shortages caused by land-use intensification, which reduces diversity and abundance of host-plant species. Bees require nectar and pollen floral resources that provide necessary carbohydrates, proteins, lipids, and micronutrients for survival, reproduction, and resilience to stress. However, nectar and pollen nutritional quality varies widely among host-plant species, which in turn influences how bees forage to obtain their nutritionally appropriate diets. Unfortunately, we know little about the nutritional requirements 
of different bee species. Research must be conducted on bee species nutritional needs and hostplant species resource quality to develop diverse and nutritionally balanced plant communities. Restoring appropriate suites of plant species to landscapes can support diverse bee species populations and their associated pollination ecosystem services. 


\section{Introduction}

A key factor driving pollinator declines is anthropogenic land-use intensification, which, among interacting factors such as pesticide use and introduced pests and pathogens, dramatically reduces the diversity and abundance of flowering plant species [1-7]. Bees (Hymenoptera: Apoidea: Anthophila), as a monophyletic group of 20,000 species [8], depend entirely on nutrition derived from floral resources (especially nectar and pollen) obtained from diverse plant species [9]. Bees therefore experience nutritional stress when limited in their choices of hostplant species or when only suboptimal floral resources are available, both of which could result in reduced population sizes and pollination efficiency [1-7]. We propose a rational approach for restoring and conserving pollinator habitat that focuses on bee nutrition by 1) determining the specific nutritional requirements of different bee species and how nutrition influences foraging

behavior and host-plant species choice, and 2) determining the nutritional quality of pollen and nectar of host-plant species. Utilizing this information, we can then 3) generate targeted plant communities that are nutritionally optimized for pollinator resource restoration and conservation. Here, we review recent literature and knowledge gaps on how floral resource nutrition and diversity influences bee health and foraging behavior. We discuss how basic research can be applied to develop rationally designed conservation protocols that support bee populations.

\section{Bee Nutrition}

Adults and larvae of nearly all bee species depend on nutrients obtained from floral resources for development, reproduction, and health $[9,10]$. Adult foragers are challenged with seeking out appropriate nutrients from the environment for developing larvae and/or nurse bees and queens 
confined to a nest [9]. At the simplest level, bee nutrition is partitioned between nectar and pollen: nectar provides bees' main source of carbohydrates, whereas pollen provides proteins, lipids, and other micronutrients [11-13]. To obtain optimal nutrition, insects can balance their nutrient intake from complementary food sources, which is considered one of the most important factors shaping foraging behavior and insect fitness [14].

Bee species likely have different quantitative and qualitative nutritional requirements, which is suggested by their differences in life history, brood size, social structure, and different distributions amongst plant species. Whereas most bees are solitary and oligolectic (a single reproductive female lays eggs and provisions brood; specializes on one plant family or genus), the majority of literature studying the nutritional needs of bees have focused on two species of long-tongued bees: honey bees and bumble bees, both of which are generalists (foraging on a wide range of plant species in different families) and social (living in colonies with cooperative brood care and overlap of generations) $[8,10,11,15]$. The nutritional requirements of honey bees (colony, adults, and larvae) has been comprehensively reviewed [10], and even though this level of detail does not exist for other bee species, we can assume that other species have similar macronutrient demands; the proportions of macronutrients required may be species-specific (as exemplified in other closely related insect species that share the same host-plants $[14,16])$.

We can infer the general dietary requirements of bees from existing research. It is clear that both adults and larvae will starve without a constant carbohydrate, mainly nectar, source [10]. Relatively immobile larvae do not require the amounts of carbohydrate needed by foraging bees and their limited carbohydrate demands can be met by a blend of pollen, which contains 
digestible carbohydrates, and nectar [17-19]. Protein concentration of pollen is positively correlated with larval development and adult reproduction (ovarian development and egg laying) in honey bees, bumble bees, and the sweat bee Lasioglossum zephyrum [20-27]. Lipids are crucial for a variety of physiological processes in bees (e.g. egg production, wax production, secondary energy source) and contribute to larval and adult health, ontogeny, and diapause/overwintering [10,27-30]. Linoleic acid (omega-6), an essential fatty acid for most insect species, in collected pollen has been associated with higher worker production in honey bee colonies [31]. A second essential fatty acid for insects, linolenic acid (omega-3), is also obtained from pollen, but its specific importance for bees is still not described [28]. Sterols obtained exclusively from pollen are the precursors for molting hormones, making pollen essential for larval development [10,27]. Recent research indicates that both honey bee and bumble bee foragers regulate their intake of carbohydrates and proteins to high ratios [32,33], and bumble bees can simultaneously regulate their intake of carbohydrates, proteins, and lipids (Vaudo et al., unpublished). These studies reveal bees' specific nutritional requirements, and potentially highlight how adults prioritize their foraging efforts between nectar and pollen for their nutritional components.

Information is lacking for the specific nutritional requirements of the vast majority of solitary oligolectic bee species, though bee taxa appear to have different requirements in nectar sugar composition (see "Nectar" discussion below). Even less is known of bees' specific pollen nutritional requirements. For at least a few species of solitary bees, pollen quantity of brood provisions is linearly correlated to body size [34]. Additionally, some specialist bees do not survive well on non-host pollen [35], suggesting that either host-plant pollen is nutritionally 
optimal for specialists, or they cannot metabolize protective chemicals of non-host pollen. Because nectar and pollen quality varies considerably between host-plant species [11,12] and the bee community exhibits different host-plant visitation patterns over time [36-38], we can assume that different bee species have specific nutritional demands that may influence their host-plant foraging patterns [16].

\section{Floral Resource Nutritional Diversity and Bee Foraging Behavior}

\section{Nectar}

Nectar is the major carbohydrate source for most bee species $[10,39,40]$. Bee larvae require carbohydrates for normal development often in the form of brood food (pollen and nectar mixtures), but the greatest quantity of carbohydrate-rich nectar is required for adult foraging [10]. Nectar is an important floral reward and reinforcing stimulus for bee foragers, and profitable nectar sources can be learned and associated with floral characteristics such as scent and color [41-43]. Although nectar is a dynamic floral resource, varying by abiotic conditions and plant age $[12,25,44-48]$, there are three relatively constant characteristics that influence bee host-plant choice for nectar: sugar composition, nectar volume, and nectar concentration [18,39]. Other characteristics of nectar composition undoubtedly play a significant role in nectar choice, such as amino acids, lipids, minerals, and secondary plant compounds [46,49-59]; however, research on these characteristics, perhaps with exception of amino acids (recently reviewed in Nepi 2014 [60], has been limited and not systematic across bee species [59-63].

The three main sugars present in nectar are glucose and fructose (monosaccharide), and sucrose (disaccharide) $[12,64,65]$. Flowers of a given taxa vary in the relative amounts of these sugars 
and plant families show a characteristic pattern of sugar composition $[12,48,64,65]$. Early research found that long-tongued bees prefer high sucrose nectars and short-tongued bees prefer nectars with a higher percentage of monosaccharides [65]. Although the interpretation of these patterns has been questioned on many levels [12,66-68], it is likely that sugar composition of plant taxa is an important factor in determining pollinator host-plant choice $[48,62,64,65,69-75]$.

Nectar concentration also determines patterns of pollinator host-plant visitation [12,76-79], limiting which pollinators can mechanically obtain the nectar, either by adhesion and capillary action or by suction. The rationale is that pollinators with long feeding apparatuses (long-tongue bees, moth/butterfly proboscis, long-tongue fly proboscis) will be limited to more dilute nectars. Although overall viscosity is affected by temperature (and sugar concentration) [80], patterns of preference are evident (reviewed by Willmer [81]) and therefore likely play a role in the evolution of plant-pollinator communities. For example, honey bees (a long-tongued bee species) prefer a concentration of 30-50\% whereas short-tongued bees utilize higher concentration nectars of $45 \%-60 \%$ [82].

It has been proposed that nectar volume, a third characteristic of floral nectar, is the result of an evolutionary tradeoff [83] between high volumes that are energetically costly (potentially influencing vegetative growth and flower production) $[84,85]$ and volumes that are too low to attract pollinators. Ideally, nectar volume of a given plant species should be high enough to attract pollinators, but low enough to ensure efficient visitation to other conspecific flowers. Nectar volume, therefore, should be strongly associated with the primary pollinators of plant taxa [86,87]. In a classic study of Costa Rican plants and their pollinators, flowers producing high 
volumes of nectar, which also had large floral mass, were visited by larger bees in contrast to smaller flowers with lower nectar volumes, which were visited by small bees and wasps [44].

\section{Pollen}

Bees obtain the majority of their protein, including free and protein bound essential amino acids, from pollen, but protein concentration varies considerably between plant species, ranging from 2-60\% [88,89]. Although preference for high protein pollen has not been clearly demonstrated for honey bees [90,91], significant decreases in pollen protein in the colony result in higher pollen foraging rates [91]. It has been suggested that honey bees may prefer pollen higher in essential amino acids [92], or obtain a balance of amino acids by collecting a diverse pollen diet [89]. Increasing evidence exists that bumble bees do prefer and will increase foraging rates to pollen sources higher in protein or essential amino acid concentration [25,93-96]. Indeed, when foraging in the same habitat amongst the same host-plant species, bumble bees collect pollen higher in protein concentration than honey bees, which may be linked to different foraging strategies; bumble bees may preferentially forage for pollen quality, where honey bees may forage for quantity to meet the vast demands of the colony [97]. This tradeoff between quantity and quality likely exists in other bee species.

Pollen serves as bees' main lipid source (including essential fatty acids and sterols), and lipid concentrations from different plant species can range considerably, from 1-20\% [11]. Furthermore, the lipid-rich oily exterior of entomophilous pollen, the pollenkitt, is an important discriminative stimulus, phagostimulus, and digestible component for pollen recognition and bee nutrition [98-102]. Bees, therefore, may be cued by pollenkitt chemistry to recognize host-plant 
pollen quality, but research is sparse on how pollen lipid content and the pollenkitt influence bee foraging choice in the field.

Because protein and lipid concentrations between pollen species are variable and uncoupled $[11,13]$ (Vaudo et al., unpublished), foragers may selectively collect pollen amongst plant species to regulate their intake of these nutrients, or, alternatively, collect from a large array of host-plant species to passively achieve a nutritional balance (this may apply to generalist and oligolectic foragers alike). Research in other arthropod species, including beetles and spiders, indicates that they sense and regulate their intake of protein and lipids when choosing among food sources [103-106]. Bumble bees, for instance, appear to collect pollen diets from the field that are both high in essential amino acid and sterol content [96]. Our recent research has demonstrated that ratio of protein:lipid concentration of pollen best predicted host-plant species preference of bumble bees; and when given multiple synthetic food sources, bumble bees indeed regulated their protein and lipid intake (Vaudo et al., unpublished). These results suggest that bees potentially analyze pollen quality in multiple nutritional dimensions. Furthermore, because bees may not be able to taste protein directly [18], pollenkitt lipid and amino acid chemistry could convey information on pollen quality to bees.

Beyond proteins and lipids, pollen (and often nectar) is rich in micronutrients (e.g. vitamins and minerals) and phytochemicals (e.g. carotenoids, flavonoids, alkaloids and phenolics) that have antioxidant properties and antimicrobial activity [11,107-110]. High concentrations of secondary plant chemicals, however, as plant defenses, could be toxic to bees $[54,111,112]$. Some specialist bee species do not survive well on exclusive non-host pollen, potentially because they cannot 
metabolize these chemicals [35]. It has been suggested that oligoleges of the genus Colletes specialize on pollen of the plant subfamily Asteroideae, while generalists of Colletes do not, possibly due to differences in their ability to cope with secondary plant chemicals of Asteroideae pollen [113]. A similar trend has been observed between larvae of closely related generalist Osmia species, having differing physiological abilities to survive on the same pollen diets due to pollen protective chemicals [114]. Therefore, bees could selectively collect or avoid host-plant pollen based on its phytochemical composition.

\section{The Importance of Plant Diversity for Bee Health}

Large scale land-use that reduces floral abundance and species richness will negatively affect bee species populations through nutritional shortage in both quantity and quality of resources [1$7,115]$. For example, the recorded population declines of bumble bee and other bee species in Europe are associated with landscape-level reduction of host-plant availability $[1-7,115,116]$. Although farmland of bee-pollinated crops may provide a large quantity of floral resources, these habitats may be insufficient at maintaining healthy bees because they may only present singlesource pollen or nectar. Also, when the crop is not blooming, the landscape may have few flowering plants, affecting all bee species whose foraging periods do not discretely overlap with crop bloom. Without diverse foraging options and diets during critical periods of reproduction and development, bees may suffer negative health consequences. Additional intensification, such as agrochemical use, can further exacerbate stress, negatively affecting bee foraging behavior $[4,7,117,118]$ and fitness [7,119-121]. 
Bees should be given a range of diverse floral resources from which they can self-select their diet to meet their component nutrient requirements, which will sustain healthy populations that can endure disease and stress. For example, in bumble bees, the reproductive benefits of polyfloral pollen diets surpassed those of monofloral diets, even when lower in protein concentration [24]. Polyfloral pollen diets can provide a balance of essential amino acids and fatty acids, whose concentrations differ between species [89]. Exposure to single pollen sources, such as Lupinus crops, that contain plant defensive chemicals can be detrimental to bumble bee colony fitness [111]. Therefore, generalist bees may visit a variety of host-plant species to obtain pollen to dampen or nullify the harmful effects of pollen secondary metabolites [112]. Appropriate nutrition is necessary for bee immunity (DeGrandi-Hoffman \& Chen, this issue); diverse pollen diets can enhance bees' immunocompetence and resistance to pathogens [122,123] and pesticides [124].

\section{Applying Bee Nutrition to Floral Resource Habitat Restoration}

To alleviate the negative effects of reduced floral resource availability and interacting stressors of agricultural intensification on bee population health and crop pollination services, selective foraging habitats should be restored in sufficient quantity surrounding areas of land-change $[7,125,126]$. Thus, there is increasing demand and incentive based programs for farmers for application of agri-environmental schemes, including floral resource provisioning to support bee populations $[7,115,127,128]$. The development and design of these schemes have focused primarily on plant species that attract bee abundance and diversity. Because the bee community will visit different plant species throughout the day, season, and between years [36-38,129-131], floral diversity is the best way to attract and support multiple pollinator species over time. 
Furthermore, farmland in proximity to natural habitat and/or supplemented with floral resources will attract a wider species richness and functional-group diversity of bees that can result in higher fruit yield [132-140], and economic benefit [139].

However, plant species diversity alone is not sufficient to ensure pollinator conservation and thus the aim should be to provide nutritionally optimized floral resources. Figure 1 provides a conceptual schematic relating research and application of criteria needed to support bee populations throughout their life cycle. While other factors (nesting habitat [141], structure of the pollinator community [131]) are important for developing pollinator plantings, for this review, we focus on the bee nutrition and the role it plays selecting appropriate plants that support a nutritionally balanced and diverse community. Foremost, plants should be chosen that present floral rewards in phenological succession throughout the day and season [129-131] spanning the active periods of bee species [139]. Then, 1) determine the nutritional value of the nectar and pollen of the agricultural crop, and commercially available native and, where advisable, noninvasive exotic host-plant species (exotic plants species should only be chosen that will not compete with endemic plant species and will promote plant-pollinator community stability [142]). These studies include analyzing nectar composition, concentration, and volume, and pollen protein, lipid, and micronutrient quality. 2) Determine the nutritional needs of different bee species occupying the landscape, including those important for crop pollination. These studies can be conducted in field, semi-field, or laboratory settings correlating resource quality to nectar and pollen visitation data [94], or feeding assays using synthetic or supplemented diets [14]. 
Integrating this information will allow us to select plant-species that better meet bees' nutritional needs. Rich nectar sources diverse in their quality and quantity will provide the differing carbohydrate needs of bees and other pollinators. Further, plant species that are attractive, but whose pollen are complementary (to each other and the agricultural crop) in their protein, lipid, and micronutrient quality will allow bees to self-select their diet to balance their intake of these nutrients to maximize their reproductive output and larval development/survival. Additionally, plant communities can be designed to match the changing nutritional needs of bees throughout the growing season. For example, with a strong understanding of pollen and nectar nutritional quality, we should be able to provide pollen sources early in the season to boost worker population growth for honey bee and bumble bee colonies [143,144], and late season nectar flow for honey bee overwintering and bumble bee gyne survival $[115,145]$ (SH Woodard, abstract 0406, Entomology 2014, Austin, TX). Finally, once pollen and nectar nutritional quality is better characterized, devised plantings should support wide generalists that collect diverse resources for quantity, or selectively for nutritional value. Because generalists visit the majority of host-plant species in local plant-pollinator communities [131], achieving diversity in our plant communities will also likely maximize attractiveness to solitary or specialist species that have limited foraging distances, shorter active periods, and narrower host-plant preferences.

Developing rationally designed floral provisioning schemes that optimize pollinator nutrition requires information about the nutritional requirements of pollinators, how these shape their foraging preferences, and the nutritional profiles of a range of the floral resources of native and agricultural plant species. Integrating this information will allow development of targeted, and simplified, plant communities, which can be used for conservation of a diverse range of bee 
species in a diversity of landscapes. These healthy and abundant bee populations will then sustain agricultural production in the face of increasing demands for food in a changing environment. 


\section{Acknowledgements}

We would like to thank the Grozinger lab for their helpful discussions and critical insight to the preparation of this manuscript. Funding supporting the development of this review was provided by North American Pollinator Protection Campaign Bee Health Improvement Project Grant, USDA AFRI NIFA Predoctoral Fellowships Grant number GRANT10359159, and from an

anonymous donation to the Penn State Center for Pollinator Research. 


\section{Figure Captions}

Figure 1. Conceptual schematic presenting a holistic framework relating basic research and landscape application for bee conservation and habitat restoration. The essential research objectives are: 1) Seasonal and daily phenology of bee and plant species, 2) Bee nutritional requirements and the nutritional quality of nectar and pollen from commercially available hostplant species, and 3) Bee species nesting requirements. These research areas provide the environmental criterion necessary for supporting bees' annual life cycle: 1) Timing of blooming that matches with bee active foraging periods, 2) Nectar characteristics necessary for bee energetic needs, especially during foraging, 3) Pollen characteristics necessary for bee reproduction and development, and 4) Nesting habitat for bees to rear brood and spend periods of time of inactivity and dormancy. We can then rationally design conservation plant communities by selecting host-plant species (and natural habitat) that meet these criteria. These plant communities constitute a diversity of host-plant species optimized for bee nutrition. The outcome of a comprehensive conservation effort is that we provide a diverse group of bee species appropriate nutrition and habitat that will stabilize their populations. Healthy and diverse bee populations will then be more effective pollinators of wild host-plant and crop species. 


\section{References}

1. Biesmeijer JC, Roberts SPM, Reemer M, Ohlemüller R, Edwards M, Peeters T, Schaffers AP, Potts SG, Kleukers R, Thomas CD, et al.: Parallel declines in pollinators and insect-pollinated plants in Britain and the Netherlands. Science 2006, 313:351354.

2. Carvell C, Roy DB, Smart SM, Pywell RF, Preston CD, Goulson D: Declines in forage availability for bumblebees at a national scale. Biol Conserv 2006, 132:481-489.

3. Naug D: Nutritional stress due to habitat loss may explain recent honeybee colony collapses. Biol Conserv 2009, 142:2369-2372.

4. Potts SG, Biesmeijer JC, Kremen C, Neumann P, Schweiger O, Kunin WE: Global pollinator declines: trends, impacts and drivers. Trends Ecol Evol 2010, 25:345-353.

5. Winfree R, Bartomeus I, Cariveau DP: Native pollinators in anthropogenic habitats. Annu Rev Ecol Evol S 2011, 42:1-22.

6. ** Ollerton J, Erenler H, Edwards M, Crockett R: Pollinator declines. Extinctions of aculeate pollinators in Britain and the role of large-scale agricultural changes. Science 2014, 346:1360-1362.

Using historical data from the mid $-19^{\text {th }}$ century until present, patterns of bee and wasp extinctions in the United Kingdom are highly correlated with periods of agricultural intensification policy and practice, including those that are associated with reductions in wildflower abundance and diversity.

7. ** Goulson D, Nicholls E, Botías C, Rotheray EL: Bee declines driven by combined stress from parasites, pesticides, and lack of flowers. Science 2015, 10.1126/science. 1255957

This current review discusses the interacting and synergistic factors contributing to bee declines and potential pollination crisis, including loss of foraging and nesting habitat, monofloral diets, introduced parasites and diseases, pesticides, and phenological disruption; also included are suggestions for improvement such as restoring floral and nesting resources, reduction of pesticide use, and preventing the spread of non-native bees, parasites, and pathogens.

8. Danforth BN, Cardinal S, Praz C, Almeida EAB, Michez D: The impact of molecular data on our understanding of bee phylogeny and evolution. Annu Rev Entomol 2013, 58:57-78.

9. Michener CD: The Bees of the World. Johns Hopkins University Press; 2007.

10. ** Brodschneider R, Crailsheim K: Nutrition and health in honey bees. Apidologie 2010, 41:278-294. 
This essential and comprehensive review of honey bee nutrition throughout the lifecycle describes the variety nutrients obtained from nectar and pollen and their important effects on colony, worker, and larval behavior, development, and health; a key example of the detail needed for a variety of bee species to address their nutritional requirements.

11. Roulston TH, Cane JH: Pollen nutritional content and digestibility for animals. Plant Syst Evol 2000, 222:187-209.

12. Nicolson SW, Thornburg RW: Nectar chemistry. In Nectaries and Nectar. Edited by Nicolson SW, Nepi M, Pacini E. Springer Netherlands; 2007:215-264.

13. Campos MGR, Bogdanov S, de Almeida-Muradian LB, Szczesna T, Mancebo Y, Frigerio C, Ferreira F: Pollen composition and standardisation of analytical methods. J Apiult Res 2008, 47:154-161.

14. ** Behmer ST: Insect herbivore nutrient regulation. Annu Rev Entomol 2009, 54:165-187.

This review highlights the history, theory, methodology, and results of how insect foraging behavior is adapted to prioritize and regulate macronutrient intake to reach an optimum target for fitness, and how reaching or modifying this target can offset deleterious effects of plant secondary chemicals and other stressors; also described are specific differences in intake targets between related insect species.

15. Haydak MH: Honey bee nutrition. Annu Rev Entomol 1970, 15:143-156.

16. Behmer ST, Joern A: Coexisting generalist herbivores occupy unique nutritional feeding niches. Proc Natl Acad Sci USA 2008, 105:1977-1982.

17. Human H, Nicolson SW: Nutritional content of fresh, bee-collected and stored pollen of Aloe greatheadii var. davyana (Asphodelaceae). Phystochemistry 2006, 67:14861492.

18. Nicolson SW: Bee food: The chemistry and nutritional value of nectar, pollen and mixtures of the two. Afr Zool 2011, 46:197-204.

19. Human H, Brodschneider R, Dietemann V, Dively G, Ellis JD, Forsgren E, Fries I, Hatjina F, Hu F-L, Jaffé R, et al.: Miscellaneous standard methods for Apis mellifera research. J Apicult Res 2013, 52:1-56.

20. Sutcliffe GH, Plowright RC: The effects of pollen availability on development time in the bumble bee Bombus terricola K. (Hymenoptera: Apidae). Can J Zool 1990, 68: $1120-1123$.

21. Génissel A, Aupinel P, Bressac C, Tasei JN, Chevrier C: Influence of pollen origin on performance of Bombus terrestris micro-colonies. Entomol Exp Appl 2002, 104:329_ 336. 
22. Roulston $\mathrm{TH}, \mathrm{Cane} \mathrm{JH}$ : The effect of pollen protein concentration on body size in the sweat bee Lasioglossum zephyrum (Hymenoptera: Apiformes). Evol Ecol 2002, 16:49-65.

23. Human H, Nicolson SW, Strauss K, Pirk CWW, Dietemann V: Influence of pollen quality on ovarian development in honeybee workers (Apis mellifera scutellata). $J$ Insect Physiol 2007, 53:649-655.

24. Tasei J-N, Aupinel P: Nutritive value of $\mathbf{1 5}$ single pollens and pollen mixes tested on larvae produced by bumblebee workers (Bombus terrestris, Hymenoptera: Apidae). Apidologie 2008, 39:397-409.

25. Cardoza YJ, Harris GK, Grozinger CM: Effects of soil quality enhancement on pollinator-plant interactions. Psyche 2012, 2012:1-8.

26. Li C, Xu B, Wang Y, Feng Q, Yang W: Effects of dietary crude protein levels on development, antioxidant status, and total midgut protease activity of honey bee (Apis mellifera ligustica). Apidologie 2012, 43:576-586.

27. ** Vanderplanck M, Moerman R, Rasmont P, Lognay G, Wathelet B, Wattiez R, Michez D: How does pollen chemistry impact development and feeding behaviour of polylectic bees? PLOS ONE 2014, 9:e86209.

Using bumble bee microcolonies confined to monofloral pollen diets of varying protein and sterol quality, bumble bees collected all pollen equally, but increases in protein/amino acid and sterols lead to higher larval weight, indicating healthier offspring that could lead to more productive adults.

28. Canavoso LE, Jouni ZE, Karnas KJ, Pennington JE, Wells MA: Fat metabolism in insects. Апnи Rev Nutr 2001, 21:23-46.

29. Toth AL, Kantarovich S, Meisel AF, Robinson GE: Nutritional status influences socially regulated foraging ontogeny in honey bees. J Exp Biol 2005, 208:4641-4649.

30. Fliszkiewicz M, Wilkaniec Z: Fatty acids and amino acids in the fat body of bumblebee Bombus terrestris (L.) in diapausing and non-diapausing queens. J Api Sci 2007, 51:55-63.

31. Avni D, Hendriksma HP, Dag A, Uni Z, Shafir S: Nutritional aspects of honey beecollected pollen and constraints on colony development in the eastern Mediterranean. J Insect Physiol 2014, 69:65-73.

32. Paoli PP, Donley D, Stabler D, Saseendranath A, Nicolson SW, Simpson SJ, Wright GA: Nutritional balance of essential amino acids and carbohydrates of the adult worker honeybee depends on age. Amino Acids 2014, doi:10.1007/s00726-014-1706-2.

33. Stabler D, Paoli PP, Nicolson SW, Wright GA: Nutrient balancing of the adult worker bumblebee (Bombus terrestris) depends on its dietary source of essential 
amino acids. J Exp Biol 2015, doi:10.1242/jeb.114249.

34. Müller A, Diener S, Schnyder S, Stutz K, Sedivy C, Dorn S: Quantitative pollen requirements of solitary bees: Implications for bee conservation and the evolution of bee-flower relationships. Biol Conserv 2006, 130:604-615.

35. Praz CJ, Müller A, Dorn S: Specialized bees fail to develop on non-host pollen: do plants chemically protect their pollen? Ecology 2008, 89:795-804.

36. Olesen JM, Bascompte J, Elberling H, Jordano P: Temporal dynamics in a pollination network. Ecology 2008, 89:1573-1582.

37. Petanidou T, Kallimanis AS, Tzanopoulos J, Sgardelis SP, Pantis JD: Long-term observation of a pollination network: fluctuation in species and interactions, relative invariance of network structure and implications for estimates of specialization. Ecol Lett 2008, 11:564-575.

38. Baldock KCR, Memmott J, Ruiz-Guajardo JC, Roze D, Stone GN: Daily temporal structure in African savanna flower visitation networks and consequences for network sampling. Ecology 2011, 92:687-698.

39. Cnaani J, Thomson JD, Papaj DR: Flower choice and learning in foraging bumblebees: effects of variation in nectar volume and concentration. Ethology 2006, 112:278-285.

40. Waser NM, Ollerton J (Eds): Plant-pollinator interactions: from specialization to generalization. University of Chicago Press; 2006.

41. Raine NE, Ings TC, Dornhaus A, Saleh N, Chittka L: Adaptation, genetic drift, pleiotropy, and history in the evolution of bee foraging behavior. In Advances in the Study of Behavior. Elsevier; 2006:305-354.

42. Raine NE, Chittka L: No trade-off between learning speed and associative flexibility in bumblebees: A reversal learning test with multiple colonies. PLoS ONE 2012, 7:e45096.

43. Knauer AC, Schiestl FP: Bees use honest floral signals as indicators of reward when visiting flowers. Ecol Lett 2015, 18:135-143.

44. Opler PA: Nectar production in a tropical ecosystem. In The Biology of Nectaries. Edited by Bentley B, Elias T. Columbia University Press; 1983:30- 79.

45. Zimmermann M: Nectar production, flowering phenology, and strategies for pollination. In Plant reproductive ecology, patterns and strategies. Edited by Lovett Doust J, Lovett Doust L. Oxford University Press; 1988:157-178.

46. Corbet SA: Nectar sugar content: estimating standing crop and secretion rate in the field. Apidologie 2003, 34:1-10. 
47. Peat J, Goulson D: Effects of experience and weather on foraging rate and pollen versus nectar collection in the bumblebee, Bombus terrestris. Behav Ecol Sociobiol 2005, 58:152-156.

48. Petanidou T: Sugars in Mediterranean floral nectars: An ecological and evolutionary approach. $J$ Chem Ecol 2005, 31:1065-1088.

49. Deinzer ML, Thomson PA, Burgett DM, Isaacson DL: Pyrrolizidine alkaloids: their occurrence in honey from tansy ragwort (Senecio jacobaea L.). Science 1977, 195:497-499.

50. Rodriguez-Arce AL, Diaz N: The stability of beta-carotene in mango nectar. $J$ Agr $U$ Puerto Rico, 1992 76:101-102.

51. Roshchina VV, Roshchina VD: Excretory function of higher plants. Springer-Verlag; 1993.

52. Ecroyd CE, Franich RA, Kroese HW, Steward D: Volatile constituents of Dactylanthus taylorii flower nectar in relation to flower pollination and browsing by animals. Phytochemistry 1995, 40:1387-1389.

53. Ferreres F, Andrade P, Gil MI, Tomás-Barberán FA: Floral nectar phenolics as biochemical markers for the botanical origin of heather honey. $Z$ Lebensm Unters For 1996, 202:40-44.

54. Adler LS: The ecological significance of toxic nectar. Oikos 2000, 91:409-420.

55. Carter $\mathrm{C}$, Thornburg RW: Is the nectar redox cycle a floral defense against microbial attack? Trends Plant Sci 2004, 9:320-324.

56. Dötterl S, Schäffler I: Flower scent of floral oil-producing Lysimachia punctata as attractant for the oil-bee Macropis fulvipes. J Chem Ecol 2007, 33:441-445.

57. Petanidou T: Ecological and evolutionary aspects of floral nectars in Mediterranean habitats. In Nectaries and Nectar. Edited by Nicolson SW, Nepi M, Pacini E. Springer; 2007:343-375.

58. González-Teuber M, Heil M: Nectar chemistry is tailored for both attraction of mutualists and protection from exploiters. Plant Signal Behav 2009, 4:809-813.

59. Baker HG, Baker I: Amino-acids in nectar and their evolutionary significance. Nature 1973, 241:543-545.

60. Nepi M: Beyond nectar sweetness: the hidden ecological role of non-protein amino acids in nectar. $J$ Ecol 2014, 102:108-115.

61. Gottsberger G, Schrauwen J, Linskens HF: Amino acids and sugars in nectar, and their putative evolutionary significance. Plant Syst Evol 1984, 145:55-77. 
62. Petanidou T, Van Laere AJ, Smets E: Change in floral nectar components from fresh to senescent flowers of Capparis spinosa (Capparidaceae), a nocturnally flowering Mediterranean shrub. Plant Syst Evol 1996, 199:79-92.

63. Carter C, Shafir S, Yehonatan L, Palmer RG, Thornburg R: A novel role for proline in plant floral nectars. Naturwissenschaften 2006, 93:72-79.

64. Percival MS: Types of nectar in angiosperms. New Phytol 1961, 60:235-281.

65. Baker HG, Baker I: Floral nectar sugar constituents in relation to pollinator type. In Handbook of Experimental Pollination Ecology. Edited by Jones CE, Little RJ. Van Nostrand Reinhold; 1983:117-41.

66. Wells H, Hill PS, Wells PH: Nectarivore foraging ecology: rewards differing in sugar types. Ecol Entomol 1992, 17:280-288.

67. Willmer PG, Stone GN: Behavioral, ecological, and physiological determinants of the activity patterns of bees. In Advances in the Study of Behavior. Edited by Slater PJB, Rosenblatt JS, Snowdon CT, Roper TJ, Brockmann HJ, Naguib M. Elsevier; 2004:2038-2043.

68. Johnson SD, Nicolson SW: Evolutionary associations between nectar properties and specificity in bird pollination systems. Biology Lett 2008, 4:49-52.

69. Wykes GR: The preferences of honeybees for solutions of various sugars which occur in nectar. $J$ Exp Biol 1952, 29:511-519.

70. Percival M: Floral Biology. Pergamon Press; 1965.

71. Baker HG, Baker I: Sugar ratios in nectars. Phytochem Bull V 1979, 23:43-45.

72. Southwick EE, Loper GM, Sadwick SE: Nectar production, composition, energetics and pollinator attractiveness in spring flowers of Western New York. Am J of Bot 1981, 68:994-1002.

73. Baker HG, Baker I: Chemical constituents in nectar in relation to pollination mechanisms and phylogeny. In Biochemical Aspects of Evolutionary Biology. Edited by Nitecki MH. University of Chicago Press; 1982:131-171.

74. Baker HG, Baker I: The predictive value of nectar chemistry to the recognition of pollinator types. Israel J Bot 1990, 39:159-66.

75. Stiles FG, Freeman CE: Patterns in floral nectar characteristics of some Bird-visited plant species from Costa Rica. Biotropica 1993, 25:191.

76. Harder LD: Effects of nectar concentration and flower depth on flower handling efficiency of bumble bees. Oecologia 1986, 69:309-315. 
77. Pyke GH, Waser NM: The production of dilute nectars by hummingbird and honeyeater flowers. Biotropica 1981, 13:260.

78. Roubik DW (Ed): Pollination of Cultivated Plants in the Tropics. Vol. 118. Food \& Agriculture Org.; 1995.

79. Borrell BJ: Mechanics of nectar feeding in the orchid bee Euglossa imperialis: pressure, viscosity and flow. J Exp Biol 2006, 209:4901-4907.

80. Mathlouthi M, Génotelle J: Rheological properties of sucrose solutions and suspensions. In Sucrose. Edited by Mathlouthi M, Reiser P. Springer; 1995:126-154.

81. Willmer P: Pollination and Floral Ecology. Princeton University Press; 2011.

82. Roubik DW, Buchmann SL: Nectar selection by Melipona and Apis mellifera (Hymenoptera: Apidae) and the ecology of nectar intake by bee colonies in a tropical forest. Oecologia 1984, 61:1-10.

83. Harder LD, Williams NM, Jordan CY, Nelson WA: The effects of floral design and display on pollinator economics and pollen dispersal. In Cognitive Ecology of Pollination. Edited by Chittka L, Thomson JD. Cambridge University Press; 2001:297317.

84. Harder LD, Cruzan MB: An evaluation of the physiological and evolutionary influences of inflorescence size and flower depth on nectar production. Funct Ecol 1990, 4:559.

85. $* *$ Mu J, Peng Y, Xi X, Wu X, Griffin JN, Niklas KJ, Sun S: Domesticated honey bees evolutionarily reduce flower nectar volume in a Tibetan lotus. Ecology 2014, 95:3161-3172.

By comparing local communities of alpine lotus at increasing distances from large honey bee apiaries and conducting a common garden experiment, the researchers found that honey bees place a significant selective pressure on plants causing adaptive tradeoffs in floral characteristics; communities of plants nearer to apiaries exhibited reduced nectar volume, while increasing plant size, biomass, and number of flowers and seeds.

86. Cruden RW, Hermann SM, Peterson S: Patterns of nectar production and plantpollinator coevolution. In The Biology of Nectaries. Edited by Bentley B, Elias TS. Columbia University Press; 1983:80-125.

87. Faegri K, Van der Pijl L. Principles of Pollination Ecology. Elsevier; 2013.

88. Roulston $\mathrm{TH}$, Cane JH, Buchmann SL: What governs protein content of pollen: pollinator preferences, pollen-pistil interactions, or phylogeny? Ecol Monogr 2000, 70:617-643.

89. Weiner CN, Hilpert A, Werner M, Linsenmair KE, Blüthgen N: Pollen amino acids 
and flower specialisation in solitary bees. Apidologie 2010, 41:476-487.

90. Van Der Moezel PG, Delfs JC, Pate JS, Loneragan WA, Bell DT: Pollen selection by honeybees in shrublands of the Northern Sandplains of Western Australia. $J$ Apicult Res 1987, 264:224-232.

91. Pernal S, Currie R: The influence of pollen quality on foraging behavior in honeybees ( Apis mellifera L.). Behav Ecol Sociobiol 2001, 51:53-68.

92. Cook SM, Awmack CS, Murray DA, Williams IH: Are honey bees' foraging preferences affected by pollen amino acid composition? Ecol Entomol 2003, 28:622627.

93. Kitaoka TK, Nieh JC: Bumble bee pollen foraging regulation: role of pollen quality, storage levels, and odor. Behav Ecol Sociobiol 2008, 63:501-510.

94. Hanley ME, Franco M, Pichon S, Darvill B, Goulson D: Breeding system, pollinator choice and variation in pollen quality in British herbaceous plants. Funct Ecol 2008, 22:592-598.

95. ** Konzmann S, Lunau K: Divergent rules for pollen and nectar foraging bumblebees - A laboratory study with artificial flowers offering diluted nectar substitute and pollen surrogate. PLoS ONE 2014, 9:e91900.

In a controlled study using artificial flowers differing in nectar (sugar concentration) and pollen (powder dilutions) quality and quantity, bumble bees show preferences for increased nectar and pollen concentration and volume, though will collect all pollen if available.

96. ** Somme L, Vanderplanck M, Michez D, Lombaerde I, Moerman R, Wathelet B, Wattiez R, Lognay G, Jacquemart A-L: Pollen and nectar quality drive the major and minor floral choices of bumble bees. Apidologie 2014, 46:92-106.

By identifying the source of pollen loads of four bumble bee species, and analyzing the amino acid and sterol quality of the host-plant species' pollen, bumble bees appear to prioritize the collection of high quality pollen (amino acid and sterol concentrations) while avoiding pollen chemical defenses; the bees also preferred plant species high in nectar volume and concentration.

97. Leonhardt SD, Blüthgen N: The same, but different: pollen foraging in honeybee and bumblebee colonies. Apidologie 2011, 43:449-464.

98. Dobson HEM: Role of flower and pollen aromas in host-plant recognition by solitary bees. Oecologia 1987, 72:618-623.

99. Dobson HEM, Bergström G: The ecology and evolution of pollen odors. Plant Syst Evol 2000, 222:63-87. 
100. Cook SM, Sandoz JC, Martin AP, Murray DA, Poppy GM, Williams IH: Could learning of pollen odours by honey bees (Apis mellifera) play a role in their foraging behaviour? Physiol Entomol 2005, 30:164-174.

101. Piskorski R, Kroder S, Dorn S: Can pollen headspace volatiles and pollenkitt lipids serve as reliable chemical cues for bee pollinators? Chem Biodivers 2011, 8:577-586.

102. Pacini E, Hesse M: Pollenkitt-its composition, forms and functions. Flora 2005, 200:399-415.

103. Jensen K, Mayntz D, Toft S, Raubenheimer D, Simpson SJ: Nutrient regulation in a predator, the wolf spider Pardosa prativaga. Anim Behav 2011, 81:993-999.

104. Lee KP, Simpson SJ, Raubenheimer D: A comparison of nutrient regulation between solitarious and gregarious phases of the specialist caterpillar, Spodoptera exempta (Walker). J Insect Physiol 2004, 50:1171-1180.

105. Mayntz D, Raubenheimer D, Salomon M, Toft S, Simpson SJ: Nutrient-specific foraging in invertebrate predators. Science 2005, 307:111-113.

106. Raubenheimer D, Mayntz D, Simpson SJ, Tøft S: Nutrient-specific compensation following diapause in a predator: implications for intraguild predation. Ecology 2007, 88:2598-2608.

107. Campos MG, Webby RF, Markham KR, Mitchell KA, da Cunha AP: Age-induced diminution of free radical scavenging capacity in bee pollens and the contribution of constituent flavonoids. $J$ Agr Food Chem 2003, 51:742-745.

108. Basim E, Basim H, Özcan M: Antibacterial activities of Turkish pollen and propolis extracts against plant bacterial pathogens. J Food Eng 2006, 77:992-996.

109. LeBlanc BW, Davis OK, Boue S, DeLucca A, Deeby T: Antioxidant activity of Sonoran Desert bee pollen. Food Chem 2009, 115:1299-1305.

110. Morais M, Moreira L, Feás X, Estevinho LM: Honeybee-collected pollen from five Portuguese Natural Parks: palynological origin, phenolic content, antioxidant properties and antimicrobial activity. Food Chem Toxicol 2011, 49:1096-1101.

111. Arnold SEJ, Idrovo MEP, Arias LJL, Belmain SR, Stevenson PC: Herbivore defence compounds occur in pollen and reduce bumblebee colony fitness. J Chem Ecol 2014, doi:10.1007/s10886-014-0467-4.

112. ** Eckhardt M, Haider M, Dorn S, Müller A: Pollen mixing in pollen generalist solitary bees: a possible strategy to complement or mitigate unfavourable pollen properties? J Anim Ecol 2014, doi:10.1111/1365-2656.12168.

For the pollen generalist Osmis cornuta, larval survival, development time, and adult body mass are negatively affected by the proportion of unfavorable pollen in their diet, 
suggesting that generalists are able to dampen or nullify the toxic effects of chemical defenses by collecting pollen from a diversity of plant species.

113. Müller A, Kuhlmann M: Pollen hosts of western palaearctic bees of the genus Colletes (Hymenoptera: Colletidae): the Asteraceae paradox. Biol J Linn Soc 2008, 95:719-733.

114. Sedivy C, Müller A, Dorn S: Closely related pollen generalist bees differ in their ability to develop on the same pollen diet: evidence for physiological adaptations to digest pollen. Funct Ecol 2011, 25:718-725.

115. ** Potts S, Biesmeijer K, Bommarco R, Breeze T, Carvalheiro L, Franzén M, GonzálezVaro JP, Holzschuh A, Kleijn D., Klein AM, et al.: Status and Trends of European Pollinators. Key Findings of the STEP Project. Pensoft Publishers; 2015.

This report of the multi-institutional partnership STEP (Status and Trends of European Pollinators) reviews the research and policy in Europe defining the impact of interacting factors of land-use on pollinator decline and associated agri-environmental schemes and ecological intensification used to support pollinator populations.

116. Goulson D, Lye GC, Darvill B: Decline and conservation of bumble bees. Annu Rev Entomol 2008, 53:191-208.

117. Gill RJ, Ramos-Rodriguez O, Raine NE: Combined pesticide exposure severely affects individual- and colony-level traits in bees. Nature 2012, 491:105-108.

118. Gill RJ, Raine NE: Chronic impairment of bumblebee natural foraging behaviour induced by sublethal pesticide exposure. Funct Ecol 2014, 28:1459-1471.

119. Whitehorn PR, O'Connor S, Wackers FL, Goulson D: Neonicotinoid pesticide reduces bumble bee colony growth and queen production. Science 2012, 336:351-352.

120. Sandrock C, Tanadini LG, Pettis JS, Biesmeijer JC, Potts SG, Neumann P: Sublethal neonicotinoid insecticide exposure reduces solitary bee reproductive success. Agr Forest Entomol 2013, 16:119-128.

121. Sandrock C, Tanadini M, Tanadini LG, Fauser-Misslin A, Potts SG, Neumann P: Impact of chronic neonicotinoid exposure on honeybee colony performance and queen supersedure. PLOS ONE 2014, 9:e103592.

122. Alaux C, Ducloz F, Crauser D, Le Conte Y: Diet effects on honeybee immunocompetence. Biol Lett 2010, 6:562-565.

123. ** Di Pasquale G, Salignon M, Le Conte Y, Belzunces LP, Decourtye A, Kretzschmar A, Suchail S, Brunet J-L, Alaux C: Influence of pollen nutrition on honey bee health: Do pollen quality and diversity matter? PLOS ONE 2013, 8:e72016.

In a lab-based study, when infected with Nosema, pollen quality (protein and lipid 
concentration) of monofloral and polyfloral diets was positively correlated to nurse honey bee physiology, immunity, and survival.

124. Schmehl DR, Teal PEA, Frazier JL, Grozinger CM: Genomic analysis of the interaction between pesticide exposure and nutrition in honey bees (Apis mellifera). J Insect Physiol 2014, 71:177-190.

125. ** Bommarco R, Kleijn D, Potts SG: Ecological intensification: harnessing ecosystem services for food security. Trends Ecol Evol 2013, 28:230-238.

This review presents a conceptual framework for utilizing "ecological intensification" to protect ecosystem services, including pollination, to meet the increasing demands for agricultural productivity and global food security.

126. Scheper J, Holzschuh A, Kuussaari M, Potts SG, Rundlöf M, Smith HG, Kleijn D: Environmental factors driving the effectiveness of European agri-environmental measures in mitigating pollinator loss - a meta-analysis. Ecol Lett 2013, 16:912-920.

127. Potts SG, Biesmeijer JC, Bommarco R, Felicioli A, Fischer M, Jokinen P, Kleijn D, Klein A-M, Kunin WE, Neumann P, et al.: Developing European conservation and mitigation tools for pollination services: approaches of the STEP (Status and Trends of European Pollinators) project. J Apicult Res 2011, 50:152-164.

128. Vaughn M, Skinner M: Using farm bill programs for pollinator conservation. USDA NRCS Technical Note, 2008:78:1-16.

129. Vaudo AD, Patch HM, Mortensen DA, Grozinger CM, Tooker JF: Bumble bees exhibit daily behavioral patterns in pollen foraging. Arthropod-Plant Inte 2014, 8:273-283.

130. Basilio AM, Medan D, Torretta JP, Bartoloni NJ: A year-long plant-pollinator network. Austral Ecol 2006, 31:975-983.

131. Russo L, DeBarros N, Yang S, Shea K, Mortensen D: Supporting crop pollinators with floral resources: network-based phenological matching. Ecol Evol 2013, 3:3125-3140.

132. Kremen C, Williams NM, Thorp RW: Crop pollination from native bees at risk from agricultural intensification. Proc Natl Acad Sci USA 2002, 99:16812-16816.

133. Westphal C, Steffan-Dewenter I, Tscharntke T: Mass flowering crops enhance pollinator densities at a landscape scale. Ecol Lett 2003, 6:961-965.

134. Hoehn P, Tscharntke T, Tylianakis JM, Steffan-Dewenter I: Functional group diversity of bee pollinators increases crop yield. Proc Roy Soc B-Biol Sci 2008, 275:2283-2291.

135. Ricketts TH, Regetz J, Steffan-Dewenter I, Cunningham SA, Kremen C, Bogdanski A, Gemmill-Herren B, Greenleaf SS, Klein AM, Mayfield MM, et al.: Landscape effects on crop pollination services: are there general patterns? Ecol Lett 2008, 11:499-515. 
136. Carvalheiro LG, Seymour CL, Veldtman R, Nicolson SW: Pollination services decline with distance from natural habitat even in biodiversity-rich areas. $J$ Appl Ecol 2010, 47:810-820.

137. Garibaldi LA, Steffan-Dewenter I, Kremen C, Morales JM, Bommarco R, Cunningham SA, Carvalheiro LG, Chacoff NP, Dudenhöffer JH, Greenleaf SS, et al.: Stability of pollination services decreases with isolation from natural areas despite honey bee visits. Ecol Lett 2011, 14:1062-1072.

138. Carvalheiro LG, Seymour CL, Nicolson SW, Veldtman R: Creating patches of native flowers facilitates crop pollination in large agricultural fields: mango as a case study. J Appl Ecol 2012, 49:1373-1383.

139. ** Blaauw BR, Isaacs R: Flower plantings increase wild bee abundance and the pollination services provided to a pollination-dependent crop. J Appl Ecol 2014, 51:890-898.

Over four years, by planting large patches of native perennial wildflowers that bloom throughout the season adjacent to blueberry farms, wild bee and hoverfly abundance in blueberry fields increased annually, leading to higher blueberry fruit yield that lead to exceeding the cost of establishment and maintenance of the supplementary plantings.

140. Blaauw BR, Isaacs R: Larger patches of diverse floral resources increase insect pollinator density, diversity, and their pollination of native wildflowers. Basic Appl Ecol 2014, 15:701-711.

141. Williams NM, Crone EE, Roulston TH, Minckley RL, Packer L, Potts SG: Ecological and life-history traits predict bee species responses to environmental disturbances. Biol Conserv 2010, 143:2280-2291.

142. Stouffer DB, Cirtwill AR, Bascompte I: How exotic plants integrate into pollination networks. $J$ Ecol 2014, 102:1442-1450.

143. Riedinger V, Renner M, Rundlöf M, Steffan-Dewenter I, Holzschuh A: Early massflowering crops mitigate pollinator dilution in late-flowering crops. Landscape Ecol 2013, 29:425-435.

144. Williams NM, Regetz J, Kremen C: Landscape-scale resources promote colony growth but not reproductive performance of bumble bees. Ecology 2012, 93:10491058 .

145. Röseler PF, Röseler I: Caste specific differences in fat body glycogen metabolism of the bumblebee, Bombus terrestris. Insect Biochem 1986, 16:501-508. 


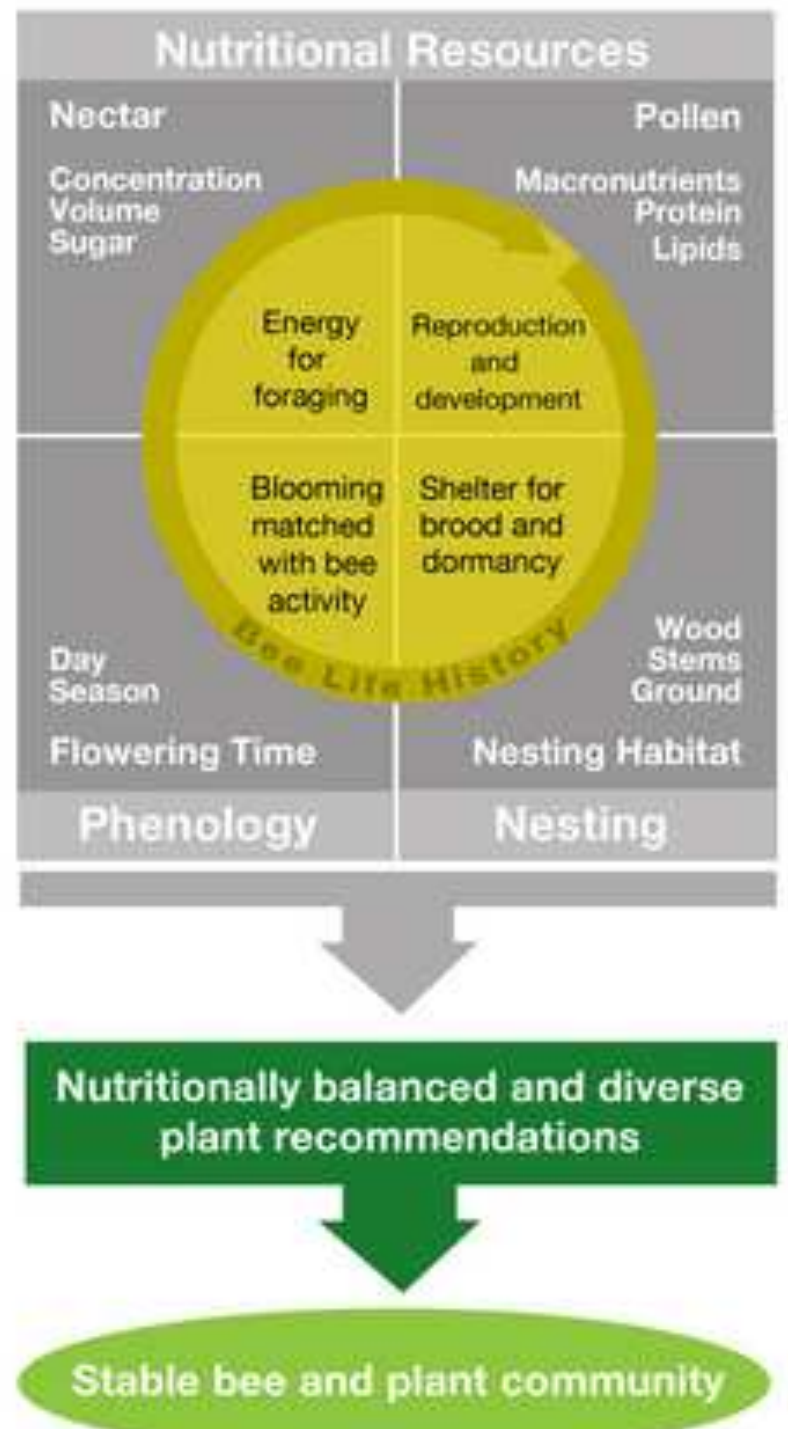

Page 29 of 29 